\title{
Chinese herbal experience for the 2019 novel coronavirus
}

\author{
Ronglin Jiang ${ }^{1}$, Kungen Wang ${ }^{1}$, Wei Mao ${ }^{1}$, Wei Zhu' ${ }^{2}$, Weihang $\mathrm{Hu}^{3}$ and Liquan Huang ${ }^{1 *}$ (D)
}

The novel coronavirus (COVID-19) has spread rapidly and become a severe global threat, with a reported acute respiratory distress syndrome (ARDS) incidence up to $40 \%$ [1]. According to a large survey, more than $14 \%$ patients were transferred to the intensive care unit care (ICU), and among those who received invasive mechanical ventilation, the mortality was as high as $88.1 \%$ [2].

Here we presented the data from a single ICU of Tianyou hospital in Wuhan, and according our experience, the overall mortality decreased in patients receiving Chinese herb therapy. From January 11, 2020, to March 17, 2020, a total of 37 patients confirmed with COVID-19 infection were admitted to ICU (Table 1), of whom seven patients were transferred to other hospitals and were excluded from this analysis. The general treatment regimens included glucocorticoids, antibiotics, hydroxychloroquine, and arbidol; however, the overall mortality rate remains as high as $78.1 \%$. Chinese herb was applied in these patients since
Feb 17. Thus, a total of nine patients received Chinese herbal therapy during the whole disease course (admitted to ICU after Feb 17), five patients received Chinese herbal therapy for a period of the whole disease course, and the rest fourteen patients had not received Chinese herbal therapy. Despite with limited sample size, the mortality rate decreased significantly after applying Chinese herbal to these patients ( $4 / 9$ vs. $5 / 5$ vs. $14 / 16, p=$ $0.033)$, especially in patients who received Chinese herbal therapy during the whole disease course. Further, these patients were also divided into two groups according to whether they had used Chinese herbal; a decreased trend of mortality was also observed (9/14 vs. $14 / 16, p=0.134)$.

We understand our finding is unstable due to the limited sample size and potential cofounders. However, in China, Chinese herbal therapy has been fully applied to patients with COVID-19 infection in the middle stage of this epidemic and the effect is positive. The following content is the

\footnotetext{
* Correspondence: huangliquan1229@163.com

'Department of Intensive Care, The First Affiliated Hospital of Zhejiang

Chinese Medical University, Hangzhou 310006, Zhejiang, People's Republic of China

Full list of author information is available at the end of the article
}

(c) The Author(s). 2020 Open Access This article is licensed under a Creative Commons Attribution 4.0 International License, which permits use, sharing, adaptation, distribution and reproduction in any medium or format, as long as you give appropriate credit to the original author(s) and the source, provide a link to the Creative Commons licence, and indicate if changes were made. The images or other third party material in this article are included in the article's Creative Commons licence, unless indicated otherwise in a credit line to the material. If material is not included in the article's Creative Commons licence and your intended use is not permitted by statutory regulation or exceeds the permitted use, you will need to obtain permission directly from the copyright holder. To view a copy of this licence, visit http://creativecommons.org/licenses/by/4.0/ The Creative Commons Public Domain Dedication waiver (http://creativecommons.org/publicdomain/zero/1.0/) applies to the data made available in this article, unless otherwise stated in a credit line to the data. 
Table 1 Comparisons between survivors and non-survivors with coronavirus infection

\begin{tabular}{|c|c|c|c|c|}
\hline Variables & All patients $(n=30)$ & Survivors $(n=7)$ & Non-survivors $(n=23)$ & $p$ \\
\hline Gender (male, \%) & 19 (63.3) & $7(100)$ & $12(52.1)$ & 0.029 \\
\hline Age (years, \%) & $67.4 \pm 9.2$ & $65.7 \pm 9.7$ & $67.9 \pm 9.2$ & 0.582 \\
\hline $\mathrm{PaO} 2 / \mathrm{FiO}_{2}$ & $107.7 \pm 54.5$ & $122.5 \pm 52.3$ & $102.2 \pm 55.6$ & 0.410 \\
\hline ICU length of stay & $10.5(5-14)$ & $12(10-12)$ & $10(4-15)$ & 0.402 \\
\hline Intubation rate (\%) & $18(60.0)$ & $3(42.8)$ & $15(65.2)$ & 0.290 \\
\hline \multicolumn{5}{|l|}{ Comorbidities } \\
\hline Hypertension (\%) & $10(33.3)$ & $3(42.8)$ & $7(30.4)$ & 0.657 \\
\hline Diabetes (\%) & $7(23.3)$ & $1(14.2)$ & $6(26.0)$ & 1.000 \\
\hline Use of Chinese herbal & & & & 0.033 \\
\hline The whole course (\%) & $9(30)$ & $5(71.4)$ & $4(17.3)$ & \\
\hline Part of the course (\%) & $5(16.7)$ & $0(0)$ & $5(21.7)$ & \\
\hline Not used (\%) & $16(53.3)$ & $2(28.5)$ & $14(60.8)$ & \\
\hline
\end{tabular}

main Chinese herbal formulas for these nine patients:

Formula 1: Xinren, Shigao, Gualuo, Dahuang,

Mahuang, Tinglizi, Taoren, Caoguo, Binglang,

Cangshu, Jinyinhua, Lianqiao, Hongjingtian.

Formula 2: Fuzhi, Shengjiang, Huangqi, Renshen,

Xinren, Shigao, Gualuo, Dahuang, Mahuang, Tinglizi,

Taoren, Caoguo, Binglang, Cangshu, Gancao.

\section{Authors' contributions}

L.H., K.W., and W.M. came up with the idea and designed the study. L.H and W.Z. are responsible for data extraction and verification. J.Y. and R.J. are responsible for data analysis and wrote the draft. W.H. revised the paper. The final version was approved by all authors.

\section{Funding}

Zhejiang province key research plan emergency public relations project (ID:2020C03126)

\section{Availability of data and materials}

Not applicable.

\section{Ethics approval and consent to participate}

Not applicable.

\section{Consent for publication}

Not applicable.

\section{Competing interests}

None.

\section{Author details}

'Department of Intensive Care, The First Affiliated Hospital of Zhejiang Chinese Medical University, Hangzhou 310006, Zhejiang, People's Republic of China. ${ }^{2}$ Department of Intensive Care, Tianyou Hospital Affiliated to Wuhan University Of Science \& Technology, Wuhan, HuBei, People's Republic of China. ${ }^{3}$ Department of Intensive Care, Zhejiang Hospital, No. 12, Linyin Road, Hangzhou 310000, Zhejiang, People's Republic of China.

Received: 2 July 2020 Accepted: 12 July 2020

Published online: 21 July 2020

\section{References}

1. Wu C, Chen X, Cai Y, Xia J, Zhou X, Xu S, Huang H, Zhang L, Zhou X, Du C et al: Risk factors associated with acute respiratory distress syndrome and death in patients with coronavirus disease 2019 pneumonia in Wuhan, China. JAMA Intern Med 2020.

2. Richardson S, Hirsch JS, Narasimhan M, Crawford JM, McGinn T, Davidson KW, the Northwell C-RC, Barnaby DP, Becker LB, Chelico JD, et al. Presenting characteristics, comorbidities, and outcomes among 5700 patients hospitalized with COVID-19 in the New York City area. JAMA. 2020.

\section{Publisher's Note}

Springer Nature remains neutral with regard to jurisdictional claims in published maps and institutional affiliations.
Ready to submit your research? Choose BMC and benefit from:
- fast, convenient online submission
- thorough peer review by experienced researchers in your field
- rapid publication on acceptance
- support for research data, including large and complex data types
- gold Open Access which fosters wider collaboration and increased citations
- maximum visibility for your research: over $100 \mathrm{M}$ website views per year
At BMC, research is always in progress.
Learn more biomedcentral.com/submissions 